\title{
Michael Henry Heim, 1943-2012
}

Until relatively recently, Michael Henry Heim's research profile did not fit comfortably in the scholarly world. In the minds of some, it still would not. He was acutely aware of this and tirelessly insistent that the research to which he devoted himself should be counted as not merely acceptable but legitimate. In this he was prescient, if not revolutionary.

Heim's chosen work was markedly interdisciplinary before interdisciplinarity became a buzzword; it was professionally oriented before the rise of the professional schools in American higher education; it predated the MFA writing revolution that has now made the Association of Writers and Writing Programs a rival to the Modern Language Association in size and professional impact; and it tied the basic research mission of the Research I university to outreach and public engagement long before the recent administrative emphasis on the need for outreach and engagement. Heim worked at the confluence of language learning, literary history, area studies, creative writing, and arts publishing, drawing from scholarship, his own and that of his colleagues, to create contemporary international literature in English. He would never have described his work this way, of course: most often he called himself simply a translator.

This self-description, which he would announce every year at the orientation for new graduate students, contained something of a challenge. Colleagues might have just listed a variety of specialized studies they were engaged in, or a forthcoming monograph on a relatively specialized topic, and the newly arrived students might have just been expressing their own scholarly interests and aspirations, descriptive and sometimes a little self-important, and then Heim would quietly say, "My name is Michael Heim, and I'm a translator." Sometimes he would add, "and I teach Czech," issuing, in effect, a double challenge, for this was also before the advent of secondlanguage acquisition as an accepted scholarly field as well.

An important effect of Heim's challenging self-description, which he did not of course only issue at departmental functions, was to insert translation, and language instruction, into the profile of the research-oriented language and literature department and the daily, professional activity of its members. He championed, in effect, these poor cousins to the scholarly when it was much more common for translators and language instructors to keep quiet about their work, and even sometimes hide it. But he championed them in his own distinctive way, without scholarly commentary, without theoretical intervention. His Czech language textbook (Contemporary Czech, Slavica, 1983) is uniquely practical, skills oriented, content-based, and still widely in use. Nor were there "studies" to go along with "translation" in Heim's hands. He did not advance a theory, commentary, or intervention to go along with his work. Every source was distinct, he once told me. You might have principles gleaned from experience. But a theory would more likely hurt than help. In other words, he created primary texts:

Chekhov: The Essential Plays; In Search of Melancholy Baby; The Island of Crimea; Astrophobia; A Certain Finkelmeyer; Uncle Fedya, His Dog, and His Cat; Easter Week; Talks with T. G. Masaryk; The Book of Laughter and Forgetting; The Joke; The Unbearable Lightness of Being; The Death of Mr. Baltisberger; Too Loud a Solitude; Dancing Lessons for the Advanced in Age; Prague Tales; A Bohemian Youth; The Encyclopedia of the Dead; Early Sorrows; Migrations; The Book of Blam; Mediterranean: A Cultural Landscape; Fording the Stream of Consciousness; The Number Devil: A Mathematical

Slavic Review 72, no. 2 (Summer 2013) 
Adventure; My Century; Death in Venice; Wonder; Helping Verbs of the Heart; The Melancholy of Rebirth; Jacques and His Master.

In compiling this admittedly incomplete list, I have, somewhat artificially and somewhat polemically, omitted the languages from which these works derived and the names of their original authors in order to emphasize the fact of their creation in English, the fact that all the English words in them were Heim's, and so was the initiative behind the texts, including their selection, the pitch to publishers, the championing of the often hitherto unknown authors, and the shaping and contextualization of national or regional literatures for English-language readers, sometimes down to the jacket copy itself. (Nevertheless, for the sake of accuracy, it is worth noting that the authors were Anton Chekhov, Vasilii Aksenov, Sasha Sokolov, Feliks Roziner, Eduard Uspenskii, Karel Čapek, Milan Kundera, Bohumil Hrabal, Jan Neruda, Josef Hiršal, Danilo Kiš, Miloš Crnjanski, Aleksandar Tišma, Predrag Matvejević, Dubravka Ugrešić, Hans Magnus Enzensberger, Günter Grass, Thomas Mann, Hugo Claus, Péter Esterházy, and Geörgy Konrád; and the languages were Russian, Czech, Serbian, Croatian, German, Dutch, Hungarian, French.)

That his books sold in the hundreds of thousands of copies is worth noting, along with the fact that they were reviewed regularly in leading literary and scholarly magazines and journals, with ten reviews in the New York Review of Books alone, ranking his work alongside some of the most prominent writers and cultural figures of the past several decades. All of these are obviously projects with his name attached, but there were others brought to him at embarrassingly late stages by desperate editors in need of his expertise-for a reader report, a recommendation, or even a lengthy revision of someone else's translated work-and these do not say Heim on them, though they have plenty of Heim in them. I asked him once if it bothered him that his work would not be recognized. He said it was much more important that the work be done right. If his name was not on it, so be it.

He was marvelously generous with his time, coaching his students in how to teach, working with them on their translations, editing their scholarly prose. He was adept at the tiny, apt suggestions that characterize the best editors. He had compiled a lifetime of pedagogical, translation, and language-learning principles that he shared with anyone who asked. He modeled for his students the all-around intellectual, engaged, curious, generous, enthusiastic, creative, and also reliable. The extent of his generosity was not even thoroughly recognized by many of those who knew it firsthand, as we learned only afterward about his and his wife Priscilla's generosity in establishing the PEN Translation Fund, the now no longer anonymous gift that has helped hundreds of translations into English since its inception.

On one occasion Heim characterized his translation work as a kind of legerdemain, the trick of getting readers to think they are reading a work of Japanese or French literature that they just happen to be reading in English. Several commentators have seemed to find this an attractive characterization, but it was not the only thing he ever said about it, and there was much more in what he did not say that should be remembered, in particular the consummate dedication and care with which he approached each and every work, each and every author, not to mention each and every student. There are many beneficiaries of that care and dedication. It is a legacy worth cherishing and passing on to others, so that they may cherish it as well.

RUSSELl SCOTT VALENTINO

Indiana University

January 2013 